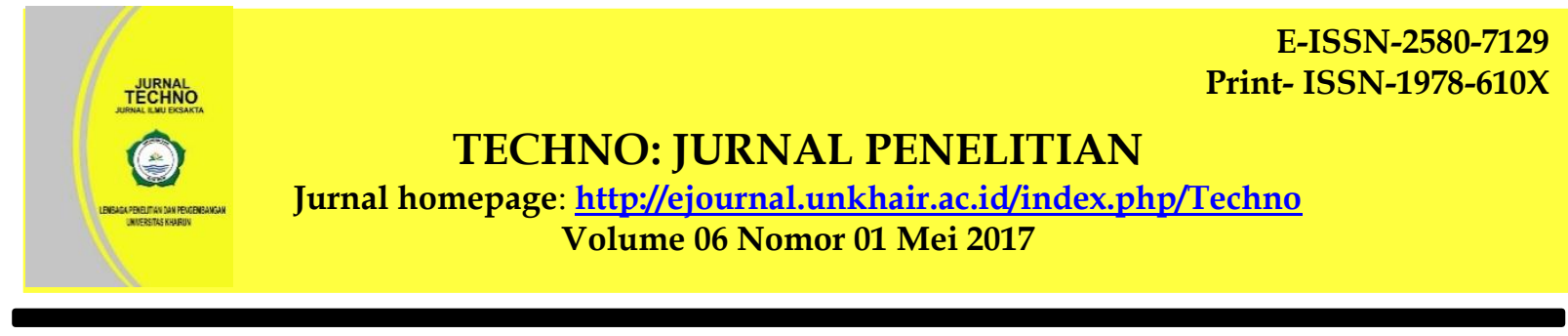

\title{
Dekomposisi Serasah Avecennia lanata pada Berbagai Tingkat Kedalaman Tanah
}

\author{
Ningsi Saibi ${ }^{*}$ dan A.R. Tolangara ${ }^{2}$ \\ 1*,2 Program Studi Pendidikan Biologi Universitas Khairun \\ *Corresponding authors: e-mail: rtolangara@yahoo.com \\ Manuscript received: 25-02-2017 Revision accepted: 29-04-2017
}

\begin{abstract}
Abstrak
Serasah mangrove berperan penting dalam kesuburan perairan pesisir. Serasah mangrove yang terdekomposisi akan menghasilkan unsur hara yang diserap oleh tanaman dan digunakan oleh jasad renik di lantai hutan dan sebagian lagi akan terlarut dan terbawa air surut ke perairan sekitarnya. Penelitian dilakukan dengan cara menghitung penyusutan bobot serasah awal yang terdekomposisi kemudian membandingkan bobot serasah yang terdekomposisi tiap bulan. Penelitian bertujuan untuk mengetahui pengaruh tingkat kedalaman tanah yang dapat mempercepat proses dekomposisi serasah. Hasil penelitian menunjukkan bahwa kedalaman tanah berpengaruh terhadap laju dekomposisi serasah jenis Avecennia lanata, tiap kedalaman tanah memiliki jenis dan jumlah mikroorganisme yang berbeda-beda, kondisi ini akan dapat berpengaruh terhadp laju dekomposisi serasah dan tingkat kedalaman $10 \mathrm{~cm}$ yang paling berpengaruh terhadap laju dekomposisi serasah Avecennia lanata yaitu yaitu sebesar 0,29-0,39 gram/hari.
\end{abstract}

Kata kunci: dekomposisi serasah, Avecennia lanata, Tingkat kedalaman tanah

\begin{abstract}
Mangrove litters play important role in coastal water fertility. The decomposed mangrove litters will produce nutrient absorbed by plants and some of them will be used by microorganisms in wood floor and the other will be dissolved and carried by the low tide to the surrounding waters. The research was conducted by calculating the depreciation of the initial weight of the decomposed litters and comparing it to the decomposed litter weight every month. The research aimed to find out the influence of soil depth that could accelerate litters decomposition process. The research result indicated that soil depth influenced the decomposition rate of Avecennia lanata litters. Each soil depth had different type and number of microorganisms. The condition would influence the decomposition rate of the litters. Soil depth of $10 \mathrm{~cm}$ was the most influential on the decomposition rate of Avecennia lanata litters, which was 0.29-0.39 gram/day.
\end{abstract}

Keywords: litters decomposition, Avecennia lanata, Soil depth

\section{PENDAHULUAN}

Mangrove merupakan suatu ekosistem dengan fungsi yang unik di kawasan pesisir. Pengaruh laut dan daratan, di kawasan ekosistem mangrove menyebabkan terjadi interaksi kompleks antara sifat fisik dan sifat biologi. Berdasarkan sifat fisik, mangrove dapat berperan sebagai 


\section{TECHNO: Vol. 06 ( 01): 11-17, Mei 2017}

penahan ombak serta penahan intrusi dan abrasi air laut (Arief, 2003). Mangrove berperan penting dalam melindungi pantai dari gelombang angin dan badai, tegakan mangrove dapat melindungi pemukiman, bangunan, lahan pertanian dari angin kencang dan intrusi air laut. Akar mangrove mampu mengikat dan menstabilkan substrat lumpur, pohonnya mengurangi energi gelombang dan memperlambat arus. Lingkungan mangrove dapat menyediakan perlindungan dan sumber makanan berupa bahan-bahan organik bagi organisme di kawasan pesisir. Mangrove juga berperan penting dalam siklus hidup berbagai jenis ikan, udang dan moluska serta sebagai pemasok bahan organik sebagai sumber makanan bagi organisme di perairan (Davies dan Clandge, 1993 dalam Noor dkk, 1999). Serasah mangrove berperan penting dalam kesuburan perairan pesisir (Nontji, 1987 dalam Noor dkk, 1999). Serasah mangrove yang terdekomposisi akan menghasilkan unsur hara yang diserap oleh tanaman dan digunakan oleh jasad renik di lantai hutan dan sebagian lagi akan terlarut dan terbawa air surut ke perairan sekitarnya.

Jumlah mikroba dalam tanah lebih banyak daripada dalam air ataupun udara. Umumnya bahan organik dan senyawa anorganik lebih tinggi dalam tanah sehingga cocok untuk pertumbuhan mikroba heterotrof maupun autotrof. Keberadaan mikroba di dalam tanah terutama dipengaruhi oleh sifat kimia dan fisika tanah. Komponen penyusun tanah yang terdiri atas pasir, debu, lempung dan bahan organik maupun bahan penyemen lain akan membentuk struktur tanah.

Penelitian ini dilkasanakan bertujuan untuk mengetahui pengaruh tingkat kedalaman tanah yang dapat mempercepat proses dekomposisi serasah.

\section{METODE PENELITIAN}

Penelitian berlokasi di area mangrove kelurahan Rum Kota Tidore Kepulauan. Alat yang akan digunakan berupa litter trap yang terbuat dari kain kasa untuk menangkap serasah daun dan ranting mangrove yang gugur, kemudian ditimbang berat basah, setelah itu dikeirngkan dengan menggunakan oven selama 24 jam dengan suhu $105^{\circ} \mathrm{C}$, setelah serasah tersebut kering, dimasukkan ke dalam kantong serasah dan di tanam di lokasi penelitian dengan kedalaman berbeda yakni $10 \mathrm{~cm}, 20 \mathrm{~cm}, 30 \mathrm{~cm}, 40 \mathrm{~cm}$ dan $50 \mathrm{~cm}$ dan diulang sebanyak 6 kali sehingga total penelitian berjumlah 30 unit. Pengamatan dilakukan setiap 2 minggu sekali selama 10 minggu dengan cara kantung serasah diambil kemudian ditimbang berat basah dan keringnya dengan maksud untuk mengetahui laju dekomposisi serasah.

Data diperoleh dengan cara menghitung penyusutan bobot serasah awal yang terdekomposisi kemudian membandingkan bobot serasah yang terdekomposisi tiap bulan, dengan menggunakan timbangan analitik yang berfungsi untuk menimbang berat basah dan berat kering serasah.

Data yang diperoleh kemudian dihitung laju dekomposisi dengan menggunakan formulasi Olson (1963) dalam Gultom (2009) sebagai berikut:

$$
\begin{gathered}
\frac{X_{t}}{X_{0}}=e^{-k t} \\
-k t=\ln \frac{X_{t}}{X_{0}}
\end{gathered}
$$


$t=\frac{\text { hari setahun }}{\text { hari lama pendekomposisian }}$

$$
\text { Dimana: } \begin{aligned}
\mathrm{X}_{\mathrm{t}} & =\text { Berat serasah setelah periode pengamatan ke-t } \\
\mathrm{Xo}_{\mathrm{o}} & =\text { Berat serasah awal } \\
\mathrm{e} & =\text { Bilangan Logaritma }(2,72) \\
\mathrm{t} & =\text { Periode Pengamatan } \\
\mathrm{k} & =\text { Laju Dekomposisi }
\end{aligned}
$$

Data yang diperoleh kemudian dianalisis dengan Analisis Varian (ANAVA) satu jalur, perlakuan yang berpengaruh nyata kemudian diuji lanjut dengan menggunakan Uji Beda Nyata Jujur (BNJ) untuk membandingkan beda rata-rata pengaruh antar perlakuan.

\section{HASIL DAN PEMBAHASAN}

Berdasarkan hasil penelitian tentang pengaruh laju dekomposisi serasah Avecennia lanata pada berbagai tingkat kedalaman tanah, diperoleh data hasil pengamatan sebagaimana disajikan pada lampiran 1. Data tersebut kemudian digunakan untuk menghitung biomassa dan dilanjutkan dengan menghitung laju dekomposisi yang cara perhitungannya terdapat pada lampiran 3. Dari data laju dekomposisi tersebut kemudian dianalisis menggunakan analisis varians (ANAVA) 1 jalur yang cara analisisnya terdapat pada lampiran 4 dan hasilnya disajikan pada Tabel 1.

Tabel 1. Hasil analisis varians laju dekomposisi serasah Avecennia lanata selama 10 minggu

\begin{tabular}{ccccccc}
\hline Sumber Varians & DB & JK & KT & F $_{\text {hit }}$ & \multicolumn{2}{c}{$\mathbf{F}_{\text {tab }}$} \\
\cline { 6 - 8 } & & & & & $\mathbf{1 \%}$ & $\mathbf{5 \%}$ \\
\hline Kelompok & 5 & 0,002 & 0,0004 & 0,4 & 4,10 & 2,71 \\
Perlakuan & 4 & 0,18 & 0,045 & $45^{* *}$ & 4,43 & 2,87 \\
Galat & 20 & 0,01 & 0,001 & & &
\end{tabular}

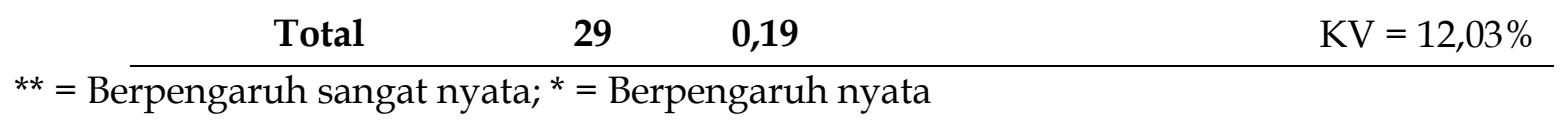

Berdasarkan hasil analisis varians di atas, dapat dilihat bahwa nilai F.hit lebih besar dibandingkan dengan nilai F.tab pada taraf signifikan 1\%, ini menunjukan bahwa, perlakuan dengan berbagai tingkat kedalaman memberikan pengaruh sangat nyata terhadap laju dekomposisi serasah Avecennia lanata.

Dengan demikian perlu diadakan uji lanjut untuk membandingkan beda rata-rata pengaruh antar perlakuan dengan menggunakan uji Beda Nyata Jujur (BNJ), yang cara analisisnya terlihat pada lampiran 5, sedangkan hasilnya dapat dilihat pada Tabel 2. 


\section{TECHNO: Vol. 06 ( 01): 11-17, Mei 2017}

Tabel 2. Hasil Uji Beda Nyata Jujur (BNJ) terhadap laju dekomposisi serasah Avecennia lanata

\begin{tabular}{cc}
\hline Perlakuan & Rata-rata \\
\hline $\mathbf{1 0} \mathbf{c m}$ & $0,33 \mathrm{c}$ \\
$\mathbf{2 0} \mathbf{c m}$ & $0,24 \mathrm{~b}$ \\
$\mathbf{3 0} \mathbf{c m}$ & $0,20 \mathrm{~b}$ \\
$\mathbf{4 0} \mathbf{c m}$ & $0,13 \mathrm{a}$ \\
$\mathbf{5 0} \mathbf{~ c m}$ & $0,11 \mathrm{a}$ \\
\hline
\end{tabular}

Ket: Angka yang diikuti dengan huruf yang sama tidak berbeda nyata.

Berdasarkan Tabel uji Beda Nyata Jujur (BNJ) pada taraf signifikan 5\%, dan dengan meilahat notasi yang telah tersaji, maka dapat dikatakan bahwa perlakuan dengan kedalaman $10 \mathrm{~cm}$ berbeda nyata terhadap perlakuan yang lainnya. Sementara perlakuan dengan kedalaman $20 \mathrm{~cm}$ tidak berbeda nyata dengan perlakuan $30 \mathrm{~cm}$, tetapi keduanya berbeda nyata dengan perlakuan lainnya. Perlakuan $40 \mathrm{~cm}$ dan $50 \mathrm{~cm}$ tidak berbeda nyata.

Menurut Satchell (1974) dalam Wijoyono (2009) dekomposisi adalah kegiatan atau proses penguraian dan pemisahan bahan-bahan organik menjadi bagian yang hancur. Dekomposisi merupakan proses penting dalam fungsi ekologis. Organisme yang telah mati mengalami penghancuran menjadi pecahan-pecahan yang lebih kecil, dan akhirnya menjadi partikel-partikel yang lebih kecil (Nybakken, 1993).

Proses dekomposisi dimulai dari proses penghancuran atau pemecahan struktur fisik yang dilakukan oleh hewan pemakan bangkai (scavenger) terhadap tumbuhan dan menyisakan sebagai bahan organik mati menjadi serasah, debris atau detritus dengan ukuran yang lebih kecil. Secara biologi bakteri yang melakukan proses secara enzimatik terhadap partikel-partikel organik. Bakteri mengeluarkan enzim protease, selulase, ligninase yang digunakan untuk menghancurkan molekul-molekul organik kompleks seperti protein dan karbohidrat dari tumbuhan yang telah mati.

Menurut Mason (1977) dalam Wijoyono (2009) terdapat 3 tahap proses dekomposisi serasah, yaitu:

1. Proses pelindihan (leaching), yaitu mekanisme hilangnya bahan-bahan yang terdapat pada serasah atau detritus akibat curah hujan atau aliran air.

2. Penghawaan (wathering), merupakan mekanisme pelapukan oleh faktor-faktor fisik seperti pengikisan oleh angin atau pergerakan molekul air.

3. Aktivitas biologi yang menghasilkan pecahan-pecahan organik oleh makhluk hidup yang melakukan dekomposisi.

\section{Kedalaman $10 \mathrm{~cm}$}

Dari hasil analisis laju dekomposisi serasah Avecennia lanata selama 10 minggu seperti yang tampak pada lampiran 4, dapat dilihat bahwa semakin dalam tanah maka laju dekomposisinya 


\section{SAIBI; TOLANGARA. DEKOMPOSISI SERASAH, Avecennia Lanata}

semakin lambat. Pada kedalaman $10 \mathrm{~cm}$ laju dekomposisi serasah A. lanata selama 70 hari sebesar 0,29-0,39 gram/hari. Ini disebabkan karena pada kedalaman $10 \mathrm{~cm}$, mikroorganisme aerobik sangat melimpah, dimana mikroorganisme tersebut membantu dalam proses perombakan bahan organik dalam tanah. Seperti yang dikemukakan oleh Askari (2010) pada kedalaman tanah 3-8 cm keberadaan organisme tiap gram tanah $\times 10^{3}$ yaitu bakteri aerob 7.800, bakteri anaerob 1.950, actinomycetes 2.080, dan fungi 119.

Dalam profil tanah yang normal lapisan tanah atas merupakan sumber unsur-unsur hara makro dan mikro esensial bagi pertumbuhan tanaman. Selain itu juga berfungsi sebagai sumber bahan organik untuk menyokong kehidupan mikroba. Keberadaan mikroba tanah dapat memainkan peranan sangat penting bagi perkembangan dan kelangsungan hidup tanaman. Aktivitasnya tidak saja terbatas pada penyediaan unsur hara, tetapi juga aktif dalam dekomposisi serasah dan bahkan dapat memperbaiki struktur tanah (Setiadi, 1996 dalam Nadalia D, 2009).

Proses dekomposisi dan keberadaan mikroorganisme juga dipengaruhi oleh keadaan iklim atau keadaan lingkungan seperti oksigen, cahaya, kelembaban, suhu, $\mathrm{pH}$ dan salinitas. Dari hasil pengukuran faktor kondisional lingkungan pada lokasi penelitian (lampiran 2), diperoleh $\mathrm{pH}$ tanah 6,4, kelembaban 25\%, suhu $31^{\circ} \mathrm{C}$, dan salinitas 28 ppt. Idawaty (1999) dalam Bahri (2006) menambahkan bahwa mikroorganisme dapat dengan cepat merombak serasah menjadi bahan organik jika $\mathrm{pH}$ tanah 5,5 atau lebih sedangkan jika $\mathrm{pH}$ di bawah 5,5 maka pertumbuhan mikroba akan terhambat sehingga laju dekomposisi serasah juga akan menurun.

Pada kedalaman $10 \mathrm{~cm}$ masih dekat dengan permukaan tanah sehingga aerasinya lancar dan ketersediaan oksigennya sangat melimpah. Oksigen diperlukan dekomposer untuk mendekomposisikan bahan organik. Menurut Isaac et al., (1993) dalam Handayanto (2007), bahwa sebaran jamur di profil tanah sangat ditentukan oleh ketersediaan karbon organik. Jika jamur memerlukan karbon dan oksigen, jamur biasanya diumpai pada profil tanah bagian atas.

\section{Kedalaman $20 \mathrm{~cm}$}

Secara umum, aktivitas mikroorganisme dalam suatu profil tanah sangat ditentukan oleh ketersediaan substrat energi dan unsur hara anorganik. Disamping itu pertumbuhan dan aktivitas mikroorganisme ditentukan oleh sifat fisik dan kimia tanah (Askari, 2010).

Dari hasil penelitian diperoleh laju dekomposisi pada kedalaman $20 \mathrm{~cm}$ yaitu 0,19-0,29 gram/hari. Pada kedalaman $20 \mathrm{~cm}$ keberadaan mikroorganisme masih banyak (bakteri aerob 1.800, bakteri anaerob 379, actinomycetes 245, dan fungi 50 tiap gram tanah $\times 10^{3}$ ) karena pada kedalaman $20 \mathrm{~cm}$ masih dekat dengan permukaan tanah yang ketersediaan oksigennya masih cukup. Menurut Saunder (1980) proses dekomposisi bakteri sangat dipengaruhi oleh kondisi

lingkungan terutama ketersediaan oksigen terlarut khususnya bakteri aerobik. Oksigen 


\section{TECHNO: Vol. 06 ( 01): 11-17, Mei 2017}

diperlukan dekomposer untuk mendekomposisikan bahan organik. Sebagaimana yang dikemukakan oleh Idawaty (1999) dalam Bahri (2006) bahwa semakin banyak bahan organik yang tersedia di dalam tanah, maka semakin tinggi pula oksigen yang dibutuhkan untuk merombaknya. Ini sejalan dengan yang dilaporkan oleh Buhang (2005) bahwa kedalaman tanah menentukan kadar bahan organik, dimana kadar bahan organik terbanyak pada lapisan tanah bagian atas atau lapisan tanah setebal $20 \mathrm{~cm}$ (15-20\%), semakin ke bawah semakin berkurang bahan organiknya.

Selain dipengaruhi oleh oksigen dan ketersediaan bahan organik, aktivitas mikroorganisme pengurai juga dipengaruhi oleh faktor lingkungan lainnya. Dari hasil pengamatan faktor kondisional lingkungan pada kedalaman $20 \mathrm{~cm}$ yaitu $\mathrm{pH}(6,3)$, suhu $\left(31^{\circ} \mathrm{C}\right)$, kelembaban $(30 \%)$ dan salinitas $(28 \mathrm{ppt})$. Setiap spesies mikroorganisme mempunyai persyaratan tertentu untuk pertumbuhannya dan jika lingkungannya tidak sesuai, pertumbuhan atau aktivitasnya akan menurun sehingga mempengaruhi total populasinya. Misalnya temperatur, sangat mempengaruhi kecepatan semua proses yang terjadi di dalam mikroorganisme. Ma'shum, et al. (2003) dalam Nadalia (2009) mengemukakan bahwa faktor lingkungan seperti $\mathrm{pH}$ tanah, bahan anorganik, kandungan bahan organik dan kelembaban tanah merupakan faktor yang berpengaruh terhadap pertumbuhan fungi. Peran utama fungi dalam kaitan dengan kesuburan tanah adalah merombak dan membantu membentuk agregat tanah.

Wijoyono (2009) melaporkan bahwa, proses dekomposisi oleh bakteri sangat dipengaruhi oleh kondisi lingkungan terutama ketersediaan oksigen terlarut khususnya bagi bakteri aerobik. Salinitas juga dapat berperan dalam membantu proses dekomposisi karena salinitas juga dapat menentukan kelimpahan jumlah makroorganisme.

\section{Kedalaman $30 \mathrm{~cm}$}

Dari hasil analisis, diperoleh laju dekomposisi pada kedalaman $30 \mathrm{~cm}$ selama 70 hari sebesar 0,200,22 gram/hari. Pada kedalaman ini laju dekomposisinya lambat, ini disebabkan karena pada kedalaman ini ketersediaan oksigen sudah sedikit sehingga keberadaan mikoorganisme aerob juga sedikit. Bukan hanya mikroorganisme aerob yang berkurang tetapi mikroorganisme anaerob, actinomycetes, fungi dan alga juga semakin berkurang dibandingkan dengan kedalaman $10 \mathrm{~cm}$ dan $20 \mathrm{~cm}$. Oksigen diperlukan dekomposer untuk mendekomposisikan bahan organik. Sebagaimana yang dikemukakan oleh Idawaty (1999) dalam Bahri (2006) bahwa semakin banyak bahan organik yang tersedia di dalam tanah, maka semakin tinggi pula oksigen yang dibutuhkan untuk merombaknya.

Selain mikroorganisme, laju dekomposisi juga dipengaruhi oleh faktor kondisi lingkungan. Faktor kondisional lingkungan pada kedalaman $30 \mathrm{~cm}$ yaitu $\mathrm{pH}(6)$, suhu $\left(31^{\circ} \mathrm{C}\right)$, kelembaban (39\%), dan salinitas (28 ppt). Suhu adalah salah satu faktor yang sangat penting bagi kehidupan 


\section{SAIBI; TOLANGARA. DEKOMPOSISI SERASAH, Avecennia Lanata}

organisme, karena suhu mempengaruhi baik aktivitas metabolisme maupun perkembangbiakan dari organisme tersebut (Hutabarat dan Evans, 1998).

Selain suhu, tegangan permukaan juga mempengaruhi keberadaan suatu mikroorganisme, tegangan permukaan berkaitan dengan kelembaban dimana distribusi mikroorganisme dalam tanah tidak merata dan terutama terdapat pada bagian organik dari partikel tanah yang mengandung cukup air. Dalam hal ini bahan organik sebagai sumber nutrien dan air berfungsi dalam metabolisme mikroorganisme.

\section{Kedalaman $40 \mathrm{~cm}$}

Pada kedalaman $40 \mathrm{~cm}$ laju dekomposisinya sudah semakin lambat (0,11-0,15 gram/hari). Ini disebabkan karena keberadaan mikroorganisme yang semakin berkurang. Organisme tanah berperan penting dalam mempercepat penyediaan hara dan juga sebagai sumber bahan organik tanah. Mikroorganisme tanah sangat nyata perannya dalam hal dekomposisi bahan organik pada tanaman tingkat tinggi. Dalam proses dekomposisi sisa tumbuhan dihancurkan atau dirombak menjadi unsur yang dapat digunakan tanaman untuk tumbuh. Mikroorganisme akan merusak tumbuhan sampai hilangnya sebagian $\mathrm{O}_{2}$ dan apabila mikroorganisme sedikit maka laju dekomposisinya pun lambat.

Faktor kondisional lingkungan pada kedalaman $40 \mathrm{~cm}$ yaitu $\mathrm{pH}$ (6), kelembaban (40\%), suhu $\left(31^{\circ} \mathrm{C}\right)$, dan salinitas (29). Salinitas juga mempengaruhi keberadaan mikroorganisme. Semakin tinggi tingkat salinitas maka semakin sedikit mikroorganisme yang mampu beradaptasi dan dapat bertahan hidup. Menurut Muslimin (1996) dalam Bahri (2007) bahwa, mikroorganisme yang terdapat pada perairan dipengaruhi oleh faktor fisik maupun kimia seperti tekanan hidrostatik, sinar, $\mathrm{pH}$, salinitas dan suhu. Salah satu respon mikroorganisme terhadap salinitas adalah tidak dapat bertoleransi dan akan mati pada kondisi salinitas tinggi. Selain itu air juga mempengaruhi aktivitas mikroorganisme sebab air merupakan komponen utama dari protoplasma. Air yang berlebih akan membatasi pertukaran gas sehingga menurunkan suplai $\mathrm{O}_{2}$, sehingga lingkungan akan menjadi anaerob.

$\mathrm{pH}$ mempengaruhi tidak saja aktivitas mikroorganisme tetapi juga keragaman spesiesnya. Aktivitas enzim mikroba tergantung pada ion $\mathrm{H}^{+}$, oleh karena itu $\mathrm{pH}$ tanah mempengaruhinya. Pada umumnya kebanyakan mikroorganisme tumbuh optimum pada kisaran pH 6-8. Meskipun demikian mikroorganisme juga masih dapat tumbuh dengan baik di luar kisaran pH tersebut (Askari, 2010).

\section{Kedalaman $50 \mathrm{~cm}$}

Laju dekomposisi pada kedalaman $50 \mathrm{~cm}$ sudah sangat lambat yaitu sebesar 0,10-0,14 gram/hari. Hal ini dikarenakan pada kedalaman $50 \mathrm{~cm}$ kelembaban tanah tinggi, $\mathrm{pH}$ semakin asam dan 


\section{TECHNO: Vol. 06 ( 01): 11-17, Mei 2017}

salinitas semakin tinggi, serta ketersediaan bahan organik juga semakin berkurang. Ini akan mempengaruhi keberadaan mikroorganisme. Kecepatan mikroorganisme tanah dalam menggunakan bahan organik jika kondisi lingkungan sesuai, maka dengan naiknya kadar bahan organik di dalam tanah makin besar pula kecepatan dekomposisinya. Buhang (2005) menyatakan bahwa semakin dalam tanah maka, semakin berkurang bahan organiknnya, sehingga keberadaan mikroba juga semakin berkurang. Selain bahan organik, keberadaan oksigen terlarut juga berkurang, sementara oksigen diperlukan dekomposer untuk mendekomposisikan bahan organik. Ini sejalan dengan yang dilaporkan oleh I.K Rengki (2011) bahwa, semakin dalamnya tanah maka keberadaan mikroorganisme oksigenik atau aerobik akan semakin berkurang. Ini disebabkan oleh ketersediaan oksigen yang semakin berkurang.

Hal ini senada dengan yang dilaporkan oleh Wijoyono (2009) bahwa, pada tingkat salinitas lebih dari $>30$ ppt didapatkan jumlah koloni bakteri paling sedikit bila dibandingkan dengan salinitas 0-10 ppt, 10-20 ppt dan 20-30 ppt. Hal ini dapat dijelaskan bahwa tingkat salintas $>30 \mathrm{ppt}$ dianggap ekstrim sehingga bakteri tidak mampu tumbuh secara optimal.

\section{KESIMPULAN}

Penelitian ini disimpulkan sebagai berikut:

1. Kedalaman tanah berpengaruh terhadap laju dekomposisi serasah jenis Avecennia lanata.

2. Tiap kedalaman tanah memiliki jenis dan jumlah mikroorganisme yang berbeda-beda, kondisi ini akan dapat berpengaruh terhadp laju dekomposisi serasah.

3. Tingkat kedalaman $10 \mathrm{~cm}$ yang paling berpengaruh terhadap laju dekomposisi serasah Avecennia lanata yaitu yaitu sebesar 0,29-0,39 gram/ hari.

\section{DAFTAR PUSTAKA}

Anonim. 2009. Produktivitas Serasah Mangrove di Daerah Tanggul Tiare. Jepara. getskripsi.com/tag/. Diakses tanggal 23 Februari 2011.

Aksornkoae, S. 1993. Ecology and Management of Mangroves. The IUCN Wetlands Programme. Bangkok. Thailand

Arief. A. 2003. Hutan Mangrove. Penerbit Kanisius. Yogyakarta.

Askari W. 2010. Tanah sebagai Habitat Mikroorganisme. http:// wordpress.com

Bahri A.F. 2007. Analisis Kandungan Nitrat dan Fosfat Pada Sedimen Mangrove yang Termanfaatkan di kec. Mallusetasi kab. Barru.

Bengen, D. G. 2003. Pedoman Teknis Pengenalan dan Pengelolaan Ekosistem Mangrove. PKSPL. IPB. Bogor

Buhang R.S. 2005. Komposisi Kandungan Bahan Organik Sedimen Lahan Mangrove Sebelah Timur Desa Tiwoho Kecamatan Wori. Skripsi. Program Studi Ilmu Kelautan. FPIK UNSRAT. Manado. 
SAIBI; TOLANGARA. DEKOMPOSISI SERASAH, Avecennia Lanata

Gardner F.P, Pearce R.B, dan Mitchell R.L. 1991. Fisiologi Tanaman Budidaya. Terjemahan. UI Press. Jakarta.

Gultom I. Marlina. 2009. Laju Dekomposisi Serasah Daun Rhizophora mucronata Pada Berbagai Tingkat Salinitas. Depertemen Kehutanan Fakultas Pertanian. Universitas Sumatera Utara.

Handayani I.P, P. Prawito dan P. Lestari. 1999. Daya Suplai Nitrogen dan Fraksionasi Pool CarbonNitrogen Labil pada Lahan Kritis. Laporan Kemajuan Riset Unggulan Terpadu VII Tahun I. Lipi - L Penelitian UNIB.

Hutabarat, S dan S. M. Evans. 1998. Pengantar Oseanografi. Direktorat Jendral Pendidikan Tinggi Departemen Pendidikan dan Kebudayaan Republik Indonesia. Jakarta

Kusmana, C. 2000. Ekologi Mangrove. Fakultas Kehutanan IPB. Bogor

I.K Rengki. 2011. Ekosistem Mangrove. http://rengkiik.blogspot.com.html. Diakses pada tanggal 15 juli 2011.

Nadalia D. 2009. Perbedaan Karakterisik Tanah Pada Lahan Reklamasi Pascatambang Dengan Tanah Asli Tanpa Top Soil (Studi Kasus di PT. Inco Sorowako, Sulawesi Selatan). Program Studi Ilmu Tanah Departemen Ilmu Tanah dan Sumberdaya Lahan Fakultas Pertanian Institut Pertanian Bogor.

Nontji, A. 2005. Laut Nusantara. Penerbit Djambatan. Jakarta.

Noor, Y. R., M. Khazali dan I.N.N. Suryadiputra. 1999. Panduan Pengenalan mangrove di Indonesia. Wetlends International-Indonesia Programe. Bogor.

Nybakken J.W. 1993. Biologi Laut Suatu Pendekatan Ekologis. Diterjemahkan oleh Eidman, Koesoebiono, D. G. Bengen, M. Hutomo dan S. Sukarjo. Gramedia. Jakarta.

Setyosari P. 2010. Metode Penelitian Pendidikan dan Pengembangan. Kencana. Malang.

Sueroyo. 1993. Pertumbuhan Mangrove dan Permasalahannya. Buletin Ilmiah INSTIPER. Yogyakarta.S

Sugandi E dan Sugiarto. 1994. Rancangan Percobaan Teori dan Aplikasi. Andi Offset. Yogyakarta.

Wijoyono. 2009. Keanekaragaman Bakteri Serasah Daun Avicennia Marina Yang Mengalami Dekomposisi Pada Berbagai Tingkat Salinitas Di Teluk Tapian Nauli. Universitas Sumatera Utara. Medan. Diakses pada tanggal 12 Maret 2011

Yunasfi. 2006. Dekomposisi Serasah Daun Avicennia marina oleh Bakteri dan Fungi pada Berbagai Tingkat Salinitas. Disertasi. Bogor: Program Studi Ilmu Pengetahuan Kehutanan, Institut Pertanian Bogor. Diakses paa tanggal 10 Januari 2011 